\title{
Bearing Capacity Improvement of Expansive Soil: Stabilization with Cement and Iron Oxide Additive
}

\author{
Sofwan ${ }^{1 *}$, Sukiman Nurdin $^{2}$ \\ ${ }^{1}$ Staf Pengajar, Jurusan Teknik Sipil, Universitas Fajar, \\ ${ }^{2}$ Staf Pengajar, Jurusan Teknik Sipil, Universitas Tadulako
}

\begin{abstract}
This research is intended to increase the bearing capacity and durability of expansive clay subgrade with Portsoil Composite Cement (PCC) and Iron Oxide additives. Using two variants of the stabilization material composition; composition-1 is soil with $5 \%$ of PCC, and composition-2 is soil with $5 \%$ PCC $+0.04 \%$ Iron Oxide). Tests include swelling potential, durability, and CBR (California Bearing Ratio). The test results showed that the performance of stabilization using composition-2 was able to reduce swelling potential on day 3 by $94.44 \%$ (14.44\% greater than using composition-1), reducing the potential for volume increment by $94.15 \%$ (greater $15.02 \%$ compared to using composition-1) and weight to $93.31 \%$ (15.32\% greater than using first). The highest CBR value in the 3 wet-dry cycle periods was nature soil $2.32 \%$, using composition- 1 reached $25.26 \%$, while using composition-2 reached $36.93 \%$ (11.67\% greater than CBR value using composition- 1 ). That the addition of $0.04 \%$ Iron Oxide to PCC-soil stabilization can significantly improve cement performance for expansive clay stabilization as a road subgrade.
\end{abstract}

\section{Introduction}

To carry a very dynamic traffic load, the structure of highway pavement can be stable if it is built on subgrade with sufficient capacity and low shrinkage capacity. Therefore expansive clay for road subgrade needs to be stabilized. Mechanical soil stabilization is done by mixing graded soil to improve its technical properties. Chemical stabilization is done by mixing a chemical to increase cohesion between grains and provide resistance to the influence of water and other chemicals that are destructive. Cement is one material that has long been used for soil stabilization. [1] stabilization with cement is suitable for non-cohesive soils, while lime is suitable for cohesive soils. Previous research has suggested that cohesive soil stabilization using cement results in a variety of characteristics, therefore a stress strain-stabilized relationship with its physical and mechanical characteristics needs to be studied [2].

Organic compounds contained in the soil delay and even inhibit the hydration process of cement, while other elements do not affect the reaction at all. Organic acids produce $\mathrm{pH}$ lower than 9 in the pores so that it greatly affects the performance of cement and can hardly increase

\footnotetext{
* Corresponding author: shofwanhd6@gmail.com
} 
strength. Oils and hydrocarbons that do not dissolve in water delay the hydration of cement but do not affect the final strength [3]. Although cement can stabilize various types of soil, it is more effective in sandy soils, sand with soil, and low to medium plasticity clay soils. While limestone is more suitable for use in high plasticity clay soils [4]. The increase in cement content for stabilization of silt-clay strength will continue to increase along with increasing cement levels to an unlimited percentage of cement content. The results showed that sandy clay added $16 \%$ cement and $4 \%$ lime at a duration of 28 days curing the UCS value increased with maximum strength reaching $3928.6 \mathrm{Kpa}$. The sandy clay added $16 \%$ cement and $6 \%$ lime at a duration of 14 days curing the UCS value increased with maximal strength reaching 198.44 Kpa. It was concluded that the increase in lime performance was more dependent on the duration of due to the pozzolanic reaction than the dose, while the increase in cement performance was more dependent on the dose [5].

The development of swelling in all soil samples tends to increase for repeated wetting processes. The trend of change in development only occurs in the second wetting process, then the next wetting process which is the 3rd and 4th tends to be stable and slightly decreases. Shrinkage in all soil samples tends to decrease in almost all samples. The tendency of changes in soil shrinkage tends to be constant until the drying cycle process for the second cycle is 10 days where this cycle is the largest shrinkage cycle that occurs. Then for the 3rd (15 days) and the 4th (20 days) drying cycle, the shrinkage process tends to be stable [6].

Mixtures of cement additives, rice husk ash and bagasse ash use levels of $4 \%$ cement, $4 \%$ cement $+6 \%$ rice husk ash, $6 \%$ cement $+8 \%$ bagasse ash. Each soil mixture experienced a wet-dry cycle of 1 period, 2 periods, and 3 periods. 1 period is 1 time soaked for 4 days and 1 time aerated for 4 days. CBR testing is done after the wet-dry cycle ends. The result was that the highest value was obtained for $4 \%$ cement without rice husk ash and bagasse ash, with a CBR value of $857.32 \%$ in the first period and continued to increase in the following period. Swelling fell $91.22 \%$, volume changes fell $82.86 \%$ and changes in weight dropped $97 \%$. [7]. The effect of the wet-dry cycle on the behaviour of sand-stabilized expansive clay using variations in the number of wet-dry cycles and variations in clay mineral content. Sand content is set at $20 \%$ of the dry mass of the soil. Artificial soil formation under conditions of optimum water content, then a wet-dry cycle is carried out on artificial soil before being tested. The results obtained that the addition of $20 \%$ sand to expansive soil does not prevent a decrease in irregular shear strength, but reduces the potential for swelling. [8]. Two samples of low plasticity clay (CL) and silt sand (ML) soil types were stabilized with cement dust. The intended cement dust is waste from the cement production process filtered on No. filter. $30(0.6 \mathrm{~mm})$. Used cement $0 \%, 5 \%, 10 \%, 15 \%$ and $20 \%$ of the dry weight of the soil. Tests carried out are shear strength, UCS, coefficient of permeability and durability. The treatment period of 1, 4, 7, 30, 60 and 90 days. The test results noted that the permeability coefficient decreased, along with the increasing proportion of cement. Soil cohesion decreases with an increasing proportion of cement. [9]

High plasticity clay soil stabilization in the liquidity index 1 and 1.25 using variations of cement water factor (FAS) and variations in cement proportions: soil using Portsoil cement type 1 to determine the increase in UCS value. FAS variations are $20 \%, 25 \%, 30 \%$ and $35 \%$ and variations in cement: soil are $5 \%, 10 \%$ and $15 \%$ of the weight of wet soil. Curing was carried out for 3 days before stabilization and the UCS test. Test specimens were tested according to the curing period of 1 day, 3 days, 7 days and 14 days. Every curing period there are 2 samples (objects) of the test, the other is tested immediately after sampling the unsoaked state and the other after soaked for 24 hours. The results showed that the maximum value of high plasticity clay UCS was obtained in the proportion of cement: soil $15 \%$ and the highest compressive strength in the proportion of FAS 35\% for unsoaked and soaked stabilization samples. [10]. Medium to bad category clays (A-7-6) stabilized with $2 \%$ cement and variations of rice husk ash from $3 \%$ to $15 \%$. The free compressive strength test results 
capacity of the original soil is $2.88 \mathrm{~kg} / \mathrm{cm}^{2}$. For various variations of rice husk ash mixture, the most effective is a mixture of $2 \% \mathrm{PC}+3 \% \mathrm{ASP}$ and $2 \% \mathrm{PC}+4 \% \mathrm{ASP}$, resulting in a free compressive strength of $3.82 \mathrm{~kg} / \mathrm{cm}^{2}$ and $3.64 \mathrm{~kg} / \mathrm{cm}^{2}$. Shows that the use of rice husk ash for soil-cement stabilization is not recommended [11]. Palangkaraya soil stabilized with cement at variations in cement content $3 \%, 6 \%, 9 \%$, and $12 \%$ on the dry weight of the soil was tested for CBR values of 3 days of and soak 4 days, and UCS for 7 days. The results showed that the optimum cement was $9.10 \%$ with a CBR value of $20 \% \geq 20 \%$ (Bina Marga) so that it met the requirements of the underwater foundation layer. Then the UCS value of 7day was $4.28 \mathrm{~kg} / \mathrm{cm} 2<6 \mathrm{~kg} / \mathrm{cm} 2$, did not meet the requirements of the underwater foundation layer [12].

In various previous studies regarding cement as a stabilizing agent in cohesive soils, it has not yielded satisfactory results. One effort to improve the performance of cement in cohesive soils is to add Iron Oxide as an additive.

The durability of road pavement construction is very dependent on the basic characteristics of the soil, including permanent deformation due to traffic load, expanding and shrinking properties due to changes in water content, uneven soil carrying capacity due to differences in soil properties at close distances or due to poor compaction.

For this layer, if tested with SNI 03-1744-1989 must have a CBR value not less than the carrying capacity characteristics of the subgrade taken for design and shown in the figure or not less than $6 \%$ if not stated otherwise (CBR after 4 days immersion if compacted $100 \%$ maximum dry density (MDD) as determined by SNI 03-1742-1989. (Division 3 General Specifications of Highways of the 3rd Revision, 2010. 3.2.2. 2) b). From various previous studies, it was found that the CBR value of the laboratory was between 1.5 times to 2 times the CBR value of the field.

\section{Methodology}

It has very high capacity and durability, but at some moisture levels, they lose their cohesive properties so that capacity decreases. Therefore, strengthening cohesion between soil needs to be done so that the soil has resistance to water and other chemicals. In this study was used as a stabilizer, Iron Oxide activator to improve cement performance in expansive clay stabilization for subgrade roads.

Tests include swelling test (swelling), durability test, and CBR (California Bearing Ratio) test. Composition-1 (100 Soils: 5 Cement), composition-2 (100 Soils: 5 Cement: 0.04 Iron Oxide). Cement used by Portsoil Composite Cement (PCC). For swelling testing, the sample was compacted at optimum water content, soaked in water, loaded with $2.82 \mathrm{Kpa}$, tested on day 3 , day 5 , and day 7 . For durability tests, for each soil mixture, a wet-dry cycle was carried out for 1 period, 2 periods, and 3 periods, 1 period was aerated once for 4 days and 1 time soaked for 4 days. Swelling and durability testing is carried out in the dry cycle period, while CBR testing is carried out after the wet-dry cycle period has ended. The laboratory of the Department of Civil Engineering, Hasanuddin University, Makassar, campus of the Gowa Engineering. The testing standards used are ASTM and SNI.

\section{Results and discussion}

\subsection{Properties of soil}

From the results of testing obtained the liquid limit value $(\mathrm{LL})=70.86 \%$ and plasticity index $(\mathrm{PI})=39.46 \%$. According to the Unified Soil Classification System (USCS) system, soil classification is classified as a type of inorganic clay with high plasticity $(\mathrm{CH})$. From the 
results of the sieve analysis, the grain size distribution was obtained, quantitatively dominated by clay fraction of $62.58 \%$, followed by silt (silt) fraction of $34.75 \%$, and a sand fraction (sand) of $2.67 \%$, so that this soil sample can be categorized as silty clay.

\subsection{Swelling behaviour}

Swelling behaviour as in Table 1 and Figure 1.

Table 1. Swelling behaviour

\begin{tabular}{|c|c|c|c|c|}
\hline Sample & $\begin{array}{c}\text { OMC } \\
\text { \% }\end{array}$ & $\begin{array}{c}\text { Swell \% } \\
\text { Days -3 }\end{array}$ & $\begin{array}{c}\text { Swell \% } \\
\text { Days-5 }\end{array}$ & $\begin{array}{c}\text { Swell \% } \\
\text { Days-7 }\end{array}$ \\
\hline Nature Soil & 28,76 & 18,00 & 0,10 & 0 \\
\hline 100 Soil : 5 Cement & 29,82 & 3,63 & 0,42 & 0 \\
\hline 100 Soil : 5 Cement : 0,04 Iron Oxide & 31,85 & 1,00 & 0 & 0 \\
\hline
\end{tabular}

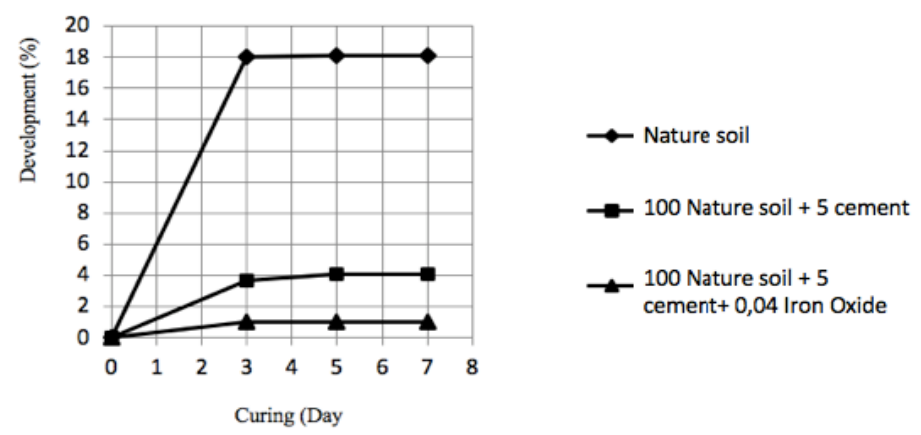

Fig.1. Correlation between\% swelling and curing time.

In Table 1 and Figure 1, the value of swelling of the original soil is $18.00 \%$. The mixture (100 soils: 5\% cement: 0.04 Iron Oxide) produces a swelling value smaller than the mixture (100 soils: 5 cement).

For mixtures (100 soil: 5 cement), at the 3 days produce swelling values of $3.63 \%$ or smaller $\{(18.00 \%-3.63 \%): 18.00 \%)\}=80.00 \%$ of the value original swelling of soil, then at the age of 5 days produce swelling values of $0.42 \%$ or smaller $\{(1.00 \%-0.42 \%): 1.00 \%)\}$ $=55.00 \%$ of the value of swelling of the original soil, and at the of 7 days there is no change in the value of swelling.

Mixture (100 soils: 5 cement: 0.04 Iron Oxide) at 3 days of age produces a swelling value of $1.00 \%$ or smaller $\{(18.00 \%-1 \%): 18 \%\}=94.44 \%$ of the swelling value original soil, then at the age of 5 days and at the age of 7 days there is no change in swelling value.

\subsection{Durability behaviour}

Durability behaviour as in Table 2 and Figure 2, Table 3 and Figure 3

Table 2. Changes in volume (\%) in the wet-dry cycle period

\begin{tabular}{|c|c|c|c|c|c|c|}
\hline \multirow{2}{*}{ Samples } & \multicolumn{6}{|c|}{ Volume change (\%) } \\
\cline { 2 - 7 } & Wet & Dry & Wet & Dry & Wet & Dry \\
\hline Nature Soil & $+20,85$ & $-2,85$ & $+1,50$ & $-1,40$ & $+1,20$ & $-1,20$ \\
\hline 100 Soil : 5 Cement & $+4,35$ & $-0,8$ & $+0,7$ & $-0,30$ & 0 & 0 \\
\hline
\end{tabular}




\begin{tabular}{|c|c|c|c|c|c|c|}
\hline $100 \begin{array}{c}\text { Soil : } 5 \text { Cement : } 0,04 \\
\text { Iron Oxide }\end{array}$ & $+1,22$ & $-0,30$ & $+0,10$ & $-0,10$ & 0 & 0 \\
\hline
\end{tabular}

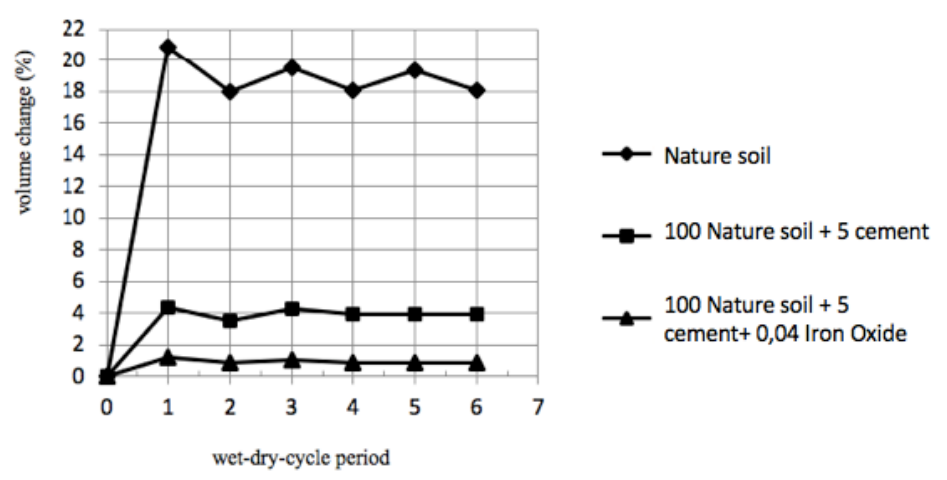

Fig.2. Correlation between $\%$ changes in volume and cycle period

Table 2 and Figure 2, in the first immersion period the original soil, experienced a volume increase of $20.85 \%$, after being dried (aerated) the original soil volume only decreased by $2.85 \%$. In the second period of immersion, the volume increase was $1.50 \%$, after drying it was reduced by $1.40 \%$. In the third period of immersion, the volume increase is $1.20 \%$, after drying it is reduced by $1.20 \%$.

The mixture (100 soil: 5 cement) in the three wet-dry cycle periods experienced the highest volume increase of $4.35 \%$ compared to the condition before $179.13 \%$ of the largest volume increase in natural soil.

The mixture (100 soils: 5 cement: 0.04 Iron Oxide) in the three wet-dry cycle periods the highest volume increase of only $1.22 \%$ compared to the condition before . of the largest volume increase in nsoil.

Table 3. Changes in weight (\%) in the wet-dry cycle period

\begin{tabular}{|c|c|c|c|c|c|c|}
\hline \multirow{2}{*}{ Sample } & \multicolumn{6}{|c|}{$\mathbf{( \% )}$} \\
\cline { 2 - 7 } & Wet & Dry & Wet & Dry & Wet & Dry \\
\hline & $+33,03$ & $-4,51$ & $+2,38$ & $-2,22$ & $+1,90$ & $-1,90$ \\
\hline $100: 5$ cement & $+7,27$ & $-1,01$ & $+0,90$ & $-0,25$ & 0 & 0 \\
\hline $\begin{array}{c}100: 5 \text { cement }: 0,04 \text { Iron } \\
\text { Oxide }\end{array}$ & $+2,21$ & $-0,50$ & $+0,20$ & $-0,20$ & 0 & 0 \\
\hline
\end{tabular}

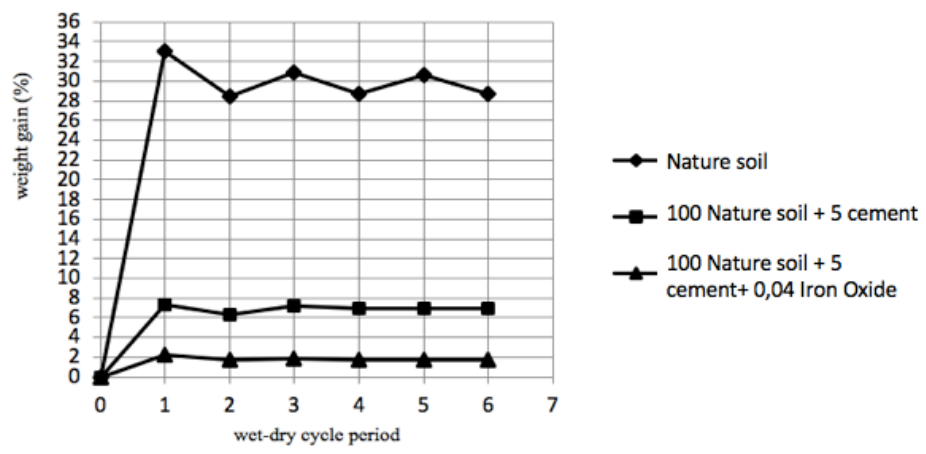

Fig.3. Correlation between $\%$ changes in weight and cycle period. 
Table 3 and Figure 3, when immersion in the first period the original soil experienced a weight gain of $33.03 \%$, after being dried (aerated) the weight of the original soil only decreased by $4.51 \%$. In the second period of immersion $2.38 \%$ weight gain, after drying reduced $2.22 \%$. In the third period of immersion, the volume increase was $1.90 \%$, after drying it was reduced by $1.90 \%$.

The mixture (100 soil: 5 cement) in the three wet-dry cycle periods experienced the greatest weight gain of $7.27 \%$ compared to the condition before soaking, or smaller $((33.03 \%$ $-7.27 \%$ ): $33.03 \%\}=77.99 \%$ of the largest weight gain on natural soil.

The mixture (100 soils: 5 cement: 0.04 Iron Oxide) in the three wet-dry cycle periods experienced the greatest weight gain of $2.21 \%$ compared to the condition before soaking, or smaller $((33.03 \%-2.21 \%): 33.03 \%\}=93.31 \%$ of the largest weight gain in natural soil.

\subsection{Support capacity (CBR).}

Support capacity (CBR) as in Table 4 and Figure 4.

Table 4. Support capacity (CBR)

\begin{tabular}{|c|c|c|c|c|}
\hline Samples & $\begin{array}{c}\text { OMC } \\
\mathbf{\%}\end{array}$ & $\begin{array}{c}\text { CBR \% } \\
\mathbf{1}\end{array}$ & $\begin{array}{c}\text { CBR \% } \\
\mathbf{2}\end{array}$ & $\begin{array}{c}\text { CBR \% } \\
\mathbf{3}\end{array}$ \\
\hline & 28,76 & 2,32 & 1,63 & 2,09 \\
\hline $100: 5$ cement & 30,55 & 11,75 & 23,31 & 25,26 \\
\hline $100: 5$ cement $: 0,04$ Iron Oxide & 27,93 & 27,65 & 33,51 & 36,93 \\
\hline
\end{tabular}

From Table 4 and Figure 4, the CBR value of the original soil is $2.32 \%$ and has a downward trend in the following period. For mixtures (100 soil: 5 cement) the CBR value in the first period was $11.75 \%$, in the second period $23.31 \%$, and in the third period $25.26 \%$. Has an increasing trend. For mixtures (100 soil: 5 cement: 0.04 Iron Oxide) the CBR value in the first period was $27.65 \%$, in the second period $33.51 \%$, in the third period $36.93 \%$. Has an increasing trend.

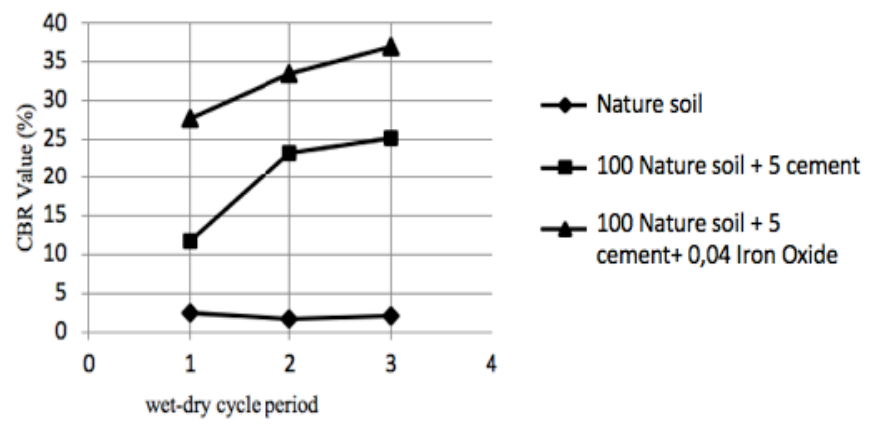

Fig.4. correlation between CBR value (\%) and wet-dry cycle period.

\section{Conclusion}

1. Stabilization performance on day 3: Using composition-1 (100 soil: 5 cement) can reduce swelling potential by $80.00 \%$, reduce the potential for volume increase by $79.13 \%$ and reduce the potential for a weight gain of $77.99 \%$. While using composition-2 (100 soils: 5 cements: 0.04 Iron Oxide) can reduce swelling potential by $94.44 \%$ (14.44\% greater than composition-1), reducing the potential for volume increase by $94.15 \%(15.02 \%$ 
greater than the composition-1) and reduced the potential for weight $93.31 \%(15.32 \%$ greater than the composition-1).

2. The highest CBR value in the 3 wet-dry cycle periods was soil $2.32 \%$, using composition1 could reach $25.26 \%$, while using composition-2 could reach $36.93 \%$ (11.67\% greater than CBR composition). -1). That the addition of $0.04 \%$ Iron Oxide to PCC-soil stabilization can significantly improve cement performance for high plasticity expansive clay stabilization as a road subgrade.

\section{References}

1. Soedarmo, G.D. dan Purnomo, S.J.E., Mekanika Tanah 2. Penerbit Kanisius Jogjakarta. (1997)

2. Wojciech SAS dan Gluchowsk.A. Effects of Stabilization with Cement on Mechanical Properties of Cohesive Soil - Sandy - Silty Clay. Annals of Warsaw University of Life Sciences - SGGW. Soil Reclamation No 45 (2), 2013: 193-205 (Ann. Warsaw Univ. of Life Sci. - SGGW, Soil Reclam. 45 (2), 2013)

3. Tremblay.H. (2002). Influence of The Nature of Organic Compounds on Fine Soil Stabilization with Cement. May (2002)

4. Pandey. A dan Rabbani. A. Stabilization of Pavement Subgrade Soil Using Lime and Cement: Review. International Research Journal of Engineering and Technology (IRJET) e-ISSN: 2395 -0056 Volume: 04 Issue: 06. June -201 (2017)

5. Sultan.T., Latif. A., Rashid, M.U., GHani, U., Khan, T.A., Khader, K. Experimental Study of Silty Clay Stabilization with Cement and Lime in Multan, Pakistan”. Technical Journal, University of Engineering and Technology (UET) Taxila, Pakistan Vol. 19 No. III- (2014)

6. Nurdin S., Samang L., Patanduk J., Harianto T., 2016., Performance of Soft Soil Stabilized by Fly Ash with Natural Fiber Reinforcement as Landfill Cover Layer., International Journal of Innovative Research in Advanced Engineering (IJIRAE). issue 12, Volume 3 (2016).

7. Putra.A.A., Zaika.Y., Harimurti. Pengaruh Penambahan Semen, Abu Sekam Padi dan Abu Ampas Tebu pada Tanah Lempung Ekspansif di Bojonegoro terhadap Nilai CBR, Swelling, dan Durabilitas. Jurusan Teknik Sipil Fakultas Teknik Universitas Brawijaya Malang Indonesia (2015)

8. Hendrikus.E.L. dan Nawir.H. Pengaruh Siklus Basah - Kering terhadap Kekuatan Geser dan Ekspansivitas Campuran Kaolin - Montmorillonit - Pasir. Jurnal Geoteknik HATTI IX (2014)

9. Al-Hassani, A.M.J., Kadhim, S.M., Fattah, A.A. Characteristics of Cohesive Soils Stabilized by Cement Kiln Dust. International Journal of Scientific \& Engineering Research, Volume 6, Issue 4, April-2015. ISSN 2229-5518 (2015)

10. Yunashirson.N.F., Purwana.Y.M., Dananjaya.R.H.. Stabilisasi Tanah Lempung Plastisitas Tinggi pada Indeks Likuiditas 1 dan 1.25 Menggunakan Semen. E-Jurnal Matriks Teknik Sipil (2015)

11. Fadilla. N. dan Roesyanto. Pengujian Kuat Tekan Bebas (Unconfined Compression Test) pada Stabilitas Tanah Lempung dengan Campuran Semen dan Abu Sekam Padi. Departemen Teknik Sipil, Universitas Sumatera Utara. (2014)

12. Muda.A., Respati.R., Puspasari.N. Stabilisasi Tanah Palangkaraya dengan Campuran Semen". Anterior Jurnal, Volume 12 Nomor 1, December, pp 43 - 47. (2012) 